\title{
Politics, Fashion and Female Agency in Parisian Salons C. i 8oo: The Case of JulietTe RÉCAMIER
}

\section{Tania Sheikhan}

In the smile which so often separates her lips of rose, you might perceive the innocent joy of a young and ravishing creature, happy to please and be loved, who saw nothing but bliss in nature, and answered the salutation of love which met her on all sides, by an expression of silent benevolence. ${ }^{1}$

7 he Duchess of Abrantès' description of Juliette de Récamier aptly demonstrates Récamier's historical reputation, beautiful, popular, and

1 fashionable, but also docile, naive, and demure. While the Duchess offered compliment, the impression we are left with is less than flattering; she conveys a society figure greatly admired yet incapable of articulating her own ideas and feelings. Abrantès praised Récamier but she also diminished her. Récamier was amiable and benevolent, 'a ravishing creature', but one of seemingly total passivity. Following a visit to Paris, British politician Charles James Fox reiterated this idea, describing the salonnière as 'the work of a Deity on a holiday': 'how sweet she is! What a smile! What a glance!'2 This is the same Récamier that critics and art historians saw in Francois Gérard's I 805 portrait (fig. I), a painting of the twenty-five-year-old reclining on a chaise longue. Récamier is depicted as a woman of resplendent leisure, wearing a white dress and gold shawl. Theresa Dolan notes that Récamier's shawl 'dominates the painting as it covered Mme Récamier's lap rather than her naked shoulders and barely concealed breasts, which are exposed to the chill of the air in the open room in which she sits'. ${ }^{3}$ It seems Récamier's primary role is to look seductively at the viewer. In these simplifications of Récamier's character, we miss the opportunity to examine just how carefully she managed her own image. The aim of this article is to shift the focus back to Récamier herself. Departing from an analysis of Gérard's portrait, I delve into the historical character of Mme Récamier, focusing on 


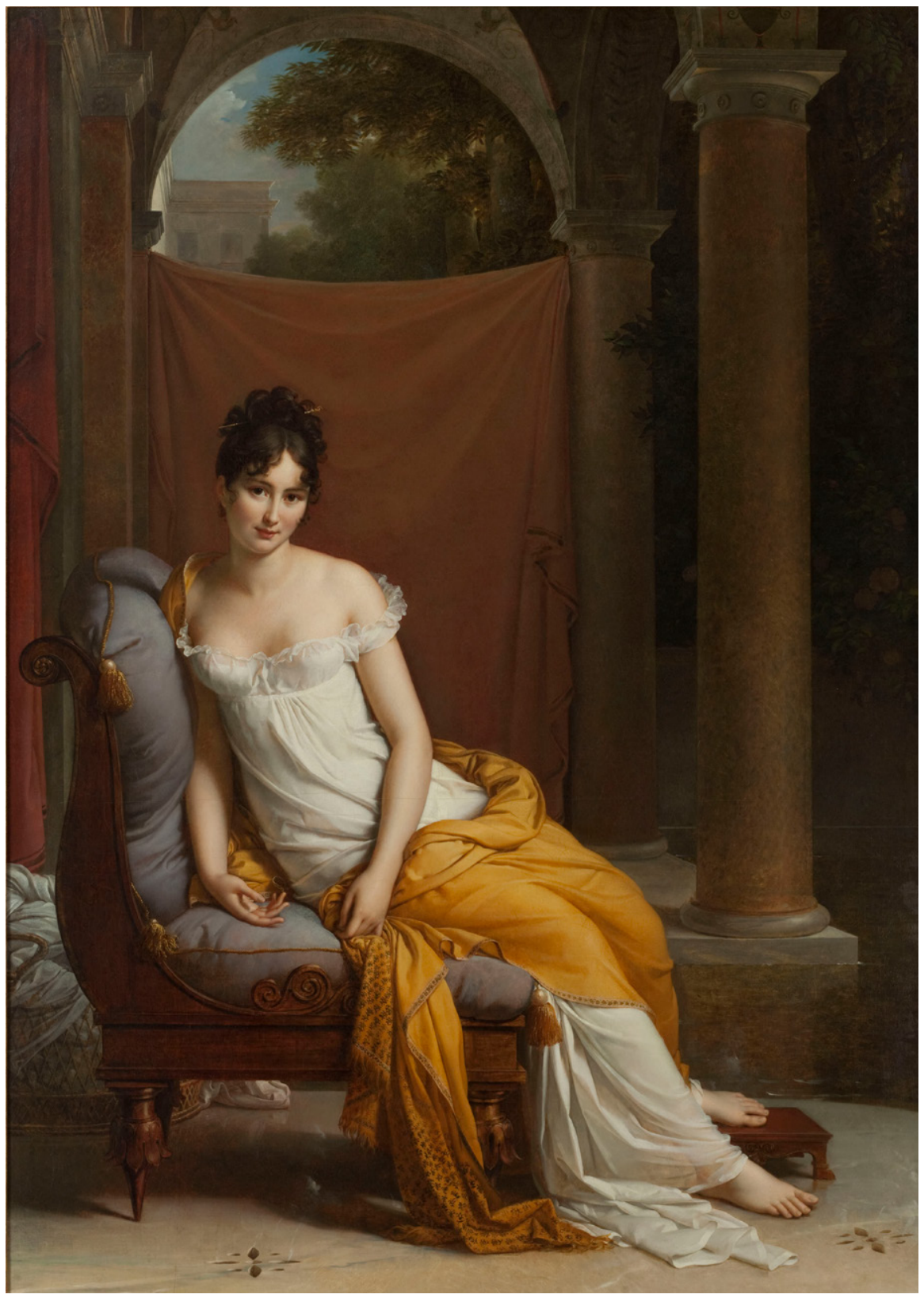

Figure I François Gérard, Madame Récamier. I 805 . Oil on canvas. $255 \times$ I $45 \mathrm{~cm}$. Musée Carnavalet, Paris. Photo: Musée Carnavalet, Paris. 
Récamier's construction of her public persona to argue that the articulation and presentation of self-image in early nineteenth-century France was no less layered and complex than the creation of material images, such as paintings and prints. In fact, I argue that Gérard's portrait is also an image of Récamier's own making. Récamier had a powerful impact in post-revolutionary French history and art, participating in the promulgation of neoclassical fashion in Europe at the very peak of its popularity. Her much-admired shawl dance, a performance she introduced at the salon she hosted, epitomised the epoch's penchant for all things classical, thus providing us with a unique model of agency, creativity, and artistry.

\section{The public image: Madame Récamier and François Gérard}

Observing post-Thermidorian society in Paris, Susan Siegfried noted a striking feature: 'Women indirectly exerting political influence through their social relations, their youth, their beauty, and their seduction, dominate the public scene'. ${ }^{4}$ Considering this period of transition, Amy Freund's work is useful for understanding the lens through which such women saw themselves. Freund explains that portraiture 'is both a private and a public art form, speaking specifically about a sitter in a language that any viewer can understand'. ${ }^{5}$ Under Bourbon rule, portraiture often paid tribute to the king and other grands hommes, and the destruction of those portraits during the Revolution demonstrated the symbolic weight of the genre. The attack of a portrait was perceived as an indirect attack on the regime represented therein. To Freund, portraiture in the I790s grappled with the crises of identity born out of the revolutionary politics: 'how to make a new people for the new France?' ${ }^{9}$ For Ewa Lajer-Burcharth, the trauma of this transitional period was marked through representations of the body. If the body was, and arguably still is, a cultural representation of the self, fashionable garments à la mode presented an attempt at reconciling what Lajer-Burcharth has described as the 'guillotine's shadow', a painful experience that had to be processed through a series of bodily practices. ${ }^{7}$ Although the body was marked by trauma, the Directoire saw a rise in self-exposure, a desire to look, and be looked at, to heal such emotional injury. One of the figures Lajerth-Burcharth highlighted as a leader in this decade of reconciliation and self-exposure was Récamier, noting that public interest reduced her body to 'a kind of aestheticised object, an incarnation of an artistic ideal'. ${ }^{8}$ Such exposure of the body as a site of 
representation, Lajer-Burcharth argued, compelled men to inquire into their own self-construction and projection. This analysis of Récamier's effect on François-René de Chateaubriand led Lajer-Burcharth to the conclusion that the salonnière 'made him feel at a loss [. . . specifically reminding him of the insufficiency of his own powers of invention'. ${ }^{9}$ Since her assessment rested on the emotional turmoil Chateaubriand experienced in observing the woman, Lajer-Burcharth displaced Récamier's agency. Chateaubriand's desires, insecurities, and anxieties were addressed more directly than the woman who provoked them. Lajer-Burcharth presented Récamier as alluring, dazzling, and beautiful, but ultimately silent.

Chateaubriand's unpleasant reminder of his own 'powers of invention' (or lack thereof) lead us to understand the complex ways in which women navigated representations of themselves. Writing on the relationship between fashion and identity, Claire E. Cage observed that 'the Revolution proscribed high fashion in the name of virtue, but with the revival of fashion under the Directory, women laid claim to the political and artistic virtues associated with the grandeur of classical antiquity'. ${ }^{10}$ In other words, the neoclassical garments worn by fashionable women in I790s Paris were in some way connected to their creativity. Women were not only consumers of fashion, but producers of ideas. Cage examines the fashion press and prints to reinforce her argument, citing a statement in the Journal de Dames et de Modes which claimed that men were simply less inventive by nature. ${ }^{11} \mathrm{Neoclassical}$ fashion was understood to be 'a product of inventive genius' as women presented themselves as mythological figures and ancient Greeks. ${ }^{12}$ The adoption of classical aesthetics now vested female fashion - normally associated with superficiality and frivolity - with elegance, taste, and creativity. ${ }^{13}$ Noting how seriously women took the art of dressing, L'Arlequin, ou Tableau des modes et des goûts states, 'following careful consultation of ancient statues,' the Parisian approach to belts dictated to women 'the belt of Juno; that of Diane was for virgins. The first is placed below the breast; it will support the throat. The second was on the hips: it marked the waist'. ${ }^{14}$

Récamier initially sat for a portrait with celebrated artist Jacques-Louis David (incidentally, also Gérard's teacher) in I80o. Encouraged by her husband, Récamier intended to display her portrait at home, for the eyes of their social circle alone. Frustrated by lack of progress with the portrait and David's dissatisfaction with his work, Jacques Récamier wrote to 
Gérard, requesting his services. ${ }^{15}$ This sealed the fate of David's painting; already displeased with it, he abandoned the project upon discovering that his pupil had also been commissioned to paint the salonnière. While a somewhat smoother process, Gérard grew increasingly irritated by the endless interruptions at his studio by Récamier's friends, all curious to visit and observe the artist at work. ${ }^{16}$ In the few letters which escaped Récamier's self-censorship, we find the voice of an opinionated woman. In an exchange dated 27 March I8I2, she wrote kindly to Gérard: 'this sweet and dreamy expression ... pleases me more than it resembles me'. ${ }^{17}$ But she also did not shy away from expressing dissatisfaction. In a missive dated I I October I 8 I I, she rebuked the artist after receiving a rough sketch: 'the figure in this drawing is extremely unpleasant, and that it in no way reminds one of the painting, ${ }^{18}$ This, perhaps more than any other document, indicates just how involved Récamier was in the making of her portrait. Indeed, in Gérard's painting, we find the duality of Récamier's character; a 'sweet and dreamy expression' affirms her modesty and innocence, but there is also evidence of the sensuality, vivacity, and sociability encapsulated by her dancing. This offers a more complex perspective on the celebrated figure at the turn of the nineteenth century.

\section{Politics and fashion in the salon}

A twenty-year-old Récamier opened her first salon at 7, Rue de MontBlanc, Paris in October I798. It was described by friends and acquaintances as elegant, tasteful, and beautifully designed. According to her adopted daughter, Amelie de Lenormant, the house marked by 'so much luxury and elegance [.. .] excited a great deal of remark'. ${ }^{19}$ May Berry, an English traveler who visited Paris frequently, praised Récamier's home for all its beautiful details: 'the chairs are mahogany enriched with ormulu, and covered either with cloth or of silk, those in the salon [are] trimmed with flat gold lace in good taste'. ${ }^{20}$ Récamier's private boudoir, Berry declared, was 'the most beautiful in Paris'. ${ }^{21}$ These writings demonstrate the salonnière's willingness to show off her good taste, as well as the importance she attached to it. Such public approval of Récamier's bon goût legitimised both her salon and her position in society.

Within the Directoire period, salons were not only spaces of sociability governed by old cultural customs, they were also a kind of mediating and 
intermediary space. $^{22}$ As Sarah Horowitz notes, such social gatherings encouraged 'politicians to get along with one another, ensuring factions remained united, and forming alliances' ${ }^{23}$ Cage points to a similar theme in her work, such spaces 'were central to the reconstitution of le monde in postThermidorian France'. ${ }^{24}$ Paradoxically, women, to whom political rights were not extended in the new republican regime, were adept at assuming leadership roles in salons, as Horowitz explains, 'as private actors, their [women's] networks could span factional divisions, facilitating alliances and socialising among different political groupings' ${ }^{25}$ As political brokering shifted from the court to the salon, a high level of public interest fell on salonnières, and on how they looked and dressed. In her salons, Récamier elicited visceral reactions with her sheer presence. Benjamin Constant describes how 'Mme. Récamier did not need to be fashionable, but perhaps fashion contributed to the universal eagerness to see her'. ${ }^{26}$

Let us now consider Récamier's careful crafting of her image under such attentiveness from her public. Regardless of the occasion, Récamier donned a white dress made of muslin or cotton, worn with very little jewelry and her hair in a simple up-do (fig. 2). Monsieur Loménie, a regular salon-goer, described her as 'dressed in white as usual [. . . her head is covered with a white muslin drapery, from which a few locks of brown hair escape, falling loosely over her forehead'. ${ }^{27}$ Pierre-Simon Ballanche joked that Récamier's white dress 'was eternal'. ${ }^{28}$ Lenormant echoes a similar thought in her memoir, writing that Récamier 'very rarely appeared in colours' and even at the 'time of her greatest wealth, she never wore diamonds'. ${ }^{29}$ This is the Récamier we see in Gérard's painting: her arms and neck are bare, illustrating the sitter's exquisitely simple taste.

It is useful to read Récamier's sartorial preferences through Amelia Rauser's recent work on the relationship between self-fashioning and neoclassical dress. Earlier notions of identity, Rauser explains, 'valued artifice as a necessary social patina'. ${ }^{30}$ For decades, the ancien régime lauded elaborately powdered wigs, panniers, and diamond-heeled shoes for how they enhanced the wearer's sophistication. Post-revolutionary neoclassical dresses - a sheer, simple material that hung tightly to the body - achieved the opposite aesthetic effect, accentuating the female form. More importantly, this style of clothing highlighted the wearer's role as a self-conscious creator of personal identity, an idea epitomised by Josephine Bonaparte. Rauser points to the 


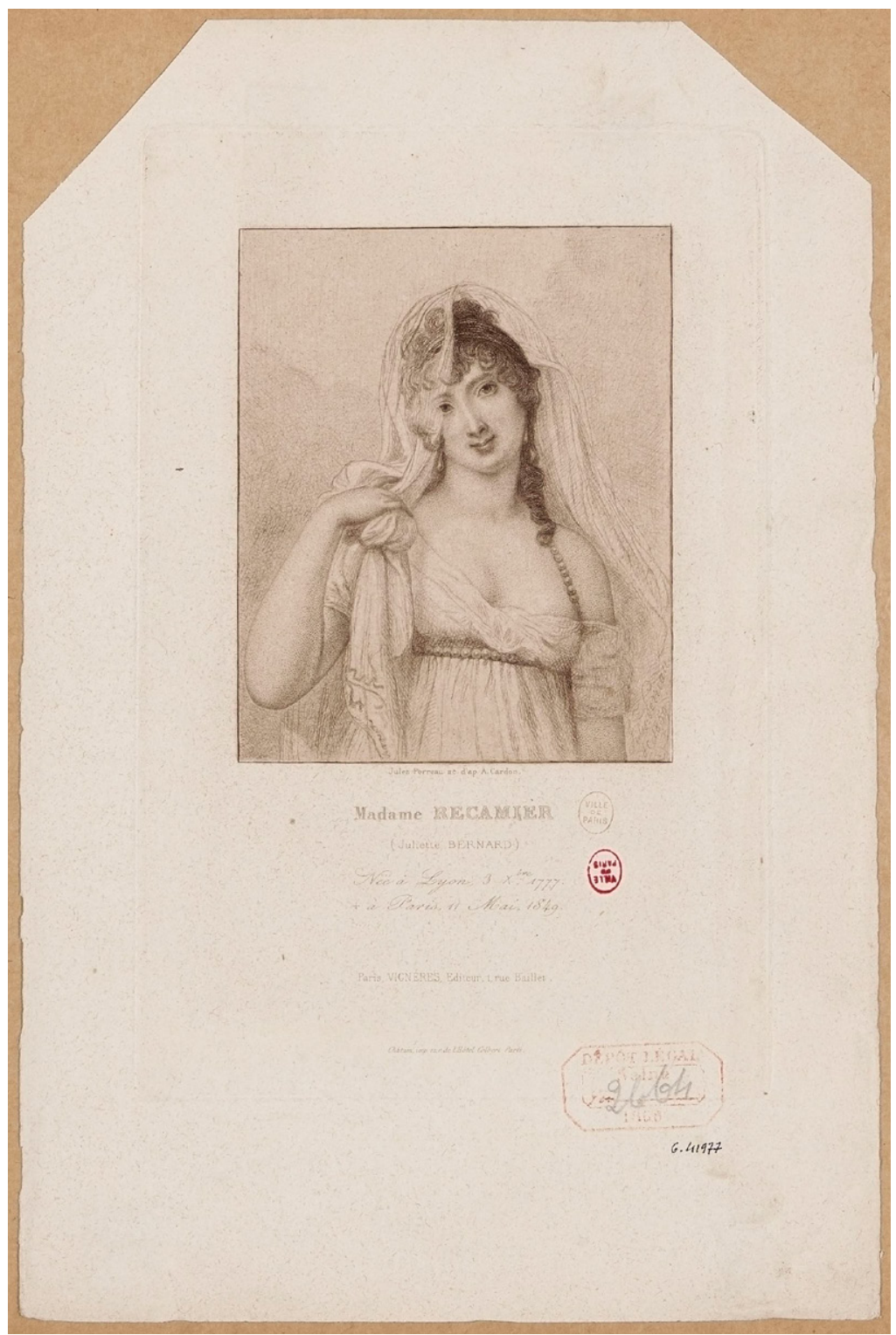

Figure 2 Jules Porreau, Juliette Bernard, dame Récamier (I777-I849). Between I 800 and I 805 . Estampe, $27.7 \times$ I $8.3 \mathrm{~cm}$. Musée Carnavalet, Paris. Photo: Musée Carnavalet. Porreau's work is a replica of Récamier's only appearance within the Journal de Dames et de Modes, in her trademark white dress. We find a not so subtle reference to her virginity: she is attired in a Tunique à la Vestale, modelled after the garb worn by Roman priestesses. 
culturally layered aesthetic that permeated Directoire culture at the time. Striving to resemble the marble statues of Hellenic culture, women sought to accentuate their own bare skin and pallor. Such classical emulation often took a sculptural form, immortalising sitters as if they were ancient statues. In the work of Lyonnais sculptor Joseph Chinard, Récamier is clad in neoclassical attire not dissimilar from the Tunique à la Vestale dress she previously modelled in Le Journal des Dames et des Modes (fig. 3). Chinard ensures her neck and décolletage are the focus, hinting at Récamier's sensuality, and once again she is without jewelry. Her head is tilted slightly and she appears to be deep in thought. Her hair is curly and a few loose tendrils illustrate her natural beauty. Récamier encapsulates the rejection of ostentation and her simplicity, or more precisely, a virtuous bon goutt. Such strategies of display put Récamier in marked contrast with other enthusiasts of neoclassical dress who were rebuked for their conspicuous consumption. Christine Adams, in her analysis of Thérésa Tallien, notes that she 'famously owned thirty blond wigs, and perhaps more than fifty in assorted colours'. ${ }^{31}$ Such decadence provoked major newspapers, such as the Abreviateur Universel; reflecting on the Revolution, one writer took a despondent tone: 'enormous luxury, concerts, the singer Garat, and the beautiful citoyenne, wife of Tallien, there you have what occupies us here'. ${ }^{32}$

Récamier's shawl dance was a staple of the gatherings at 7, Rue de MontBlanc. This talent encouraged guests to gush about what they saw. Lenormant offered the following account:

I do not know whom she learnt the shawl dance which served Mme. de Staël as a model, in Corinne. Mme. Récamier only consented to execute it while very young ... with a long scarf in her hand, she went through all the poses, wherein the light tissue becomes in turn a girdle, a veil, and a drapery. Nothing could be more graceful, more decorous, or more picturesque than this succession of harmonious attitudes, worthy to be perpetuated by the pencil of an artist. ${ }^{33}$

This description of Récamier's shawl dance has been widely quoted. Many readings focus on the inspiration of the mythical dances in Corinne, where the titular character is celebrated for her grandiose performances, which include poetry recitation and dancing the tarantella to a spellbound crowd. 


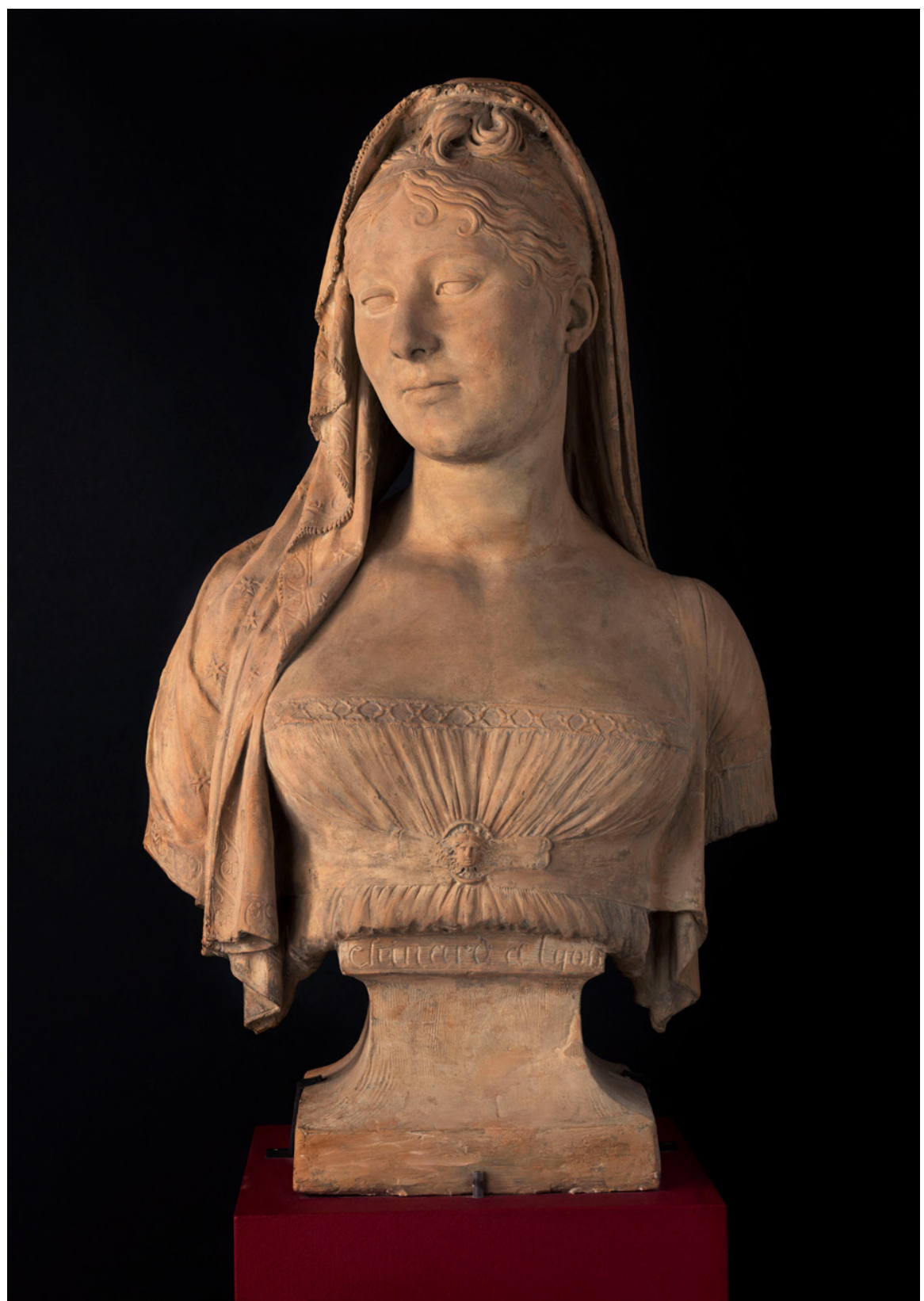

Figure 3 Joseph Chinard, Juliette Récamier. Between I 800 and I 805 . Sculpture in terracotta. $62 \times 39 \times 24 \mathrm{~cm}$. Musée Cognacq-Jay, Paris. Photo: Musée Cognacq-Jay. 
It is worth examining why Récamier chose to make a shawl dance a feature of her salon. Lenormant suggests that the success of her stepmother's salon rested in Récamier's contentment to play second fiddle to her literary friends: 'The genuine admiration she felt [...] stimulated as well as gratified them. She drew them out'. ${ }^{34}$ Saint-Beuve quipped that the young salonnière had cultivated the art of listening 'with seduction'. ${ }^{35}$ Why, then, did Récamier choose to define her salon with a performance that drew attention to herself and not her guests?

To answer this question, we must first consider dance in France in the early nineteenth-century. Sarah Davies Cordova describes it thus:

Dance was [...] both an art form and social practice in the culture of the epoch. At these events, musicians witnessed the changing dance trends; painters sketched the various settings and attempted to capture the movement of the bodies; and writers observed the social interchange which the dancing enacted. ${ }^{36}$

The attraction of dance as both a social practice and performative art is further emphasised by a number of contemporary sources. Dancers were frequently depicted in lithographs in the Journal de Dames et de Modes and Costumes Parisienne, and major newspapers such as Le Mercure or Le Gazette often discussed and analysed society balls and dances. Reflecting on dance, the Grand dictionnaire universel $d u$ XIXe siecle quipped that in 'the world of the court, it has always been more profitable to be a good dancer' ${ }^{37}$ In short, dance was synonymous with the lives of elite men and women. It was also rejuvenated by Directoire-era dresses, which allowed for a fluidity of movement and flexibility that prior styles would not permit. Observing the facility with which women now walked, Pierre de Mésangère, the editorin-chief of the Journal de Dames et de Modes, remarked on how 'in this way, a beautiful leg may be but very frequently observed'. ${ }^{38}$

At first glance, there is little in Gérard's painting indicating Récamier's penchant for performing for her guests. Although Gérard does not capture a moment during the shawl dance, it is my contention that his painting captures the sitter just after a performance. Accounts of evenings at Récamier's salon accredit this suggestion; it has been reported that after a performance, she would recline on a chaise longue and greet guests. ${ }^{39}$ In the painting, 
Récamier's cheeks are noticeably flushed, as if she had just finished dancing. Theresa Dolan suggests that Récamier seems almost 'poised to fling her shawl aside and reveal herself through the thin gauze of fabric that covers her lower body'. ${ }^{40}$ Rather than wrapping the garment around her shoulders, Récamier seems to hint at revelation, an act that begins with her bare head, shoulders, and chest. Contrary to Dolan, who interprets Récamier's gaze as coquettish, I contend that, despite the painting's erotic undertones, Récamier maintains an expression of childlike innocence (another silent reference, perhaps, to her unblemished reputation). To highlight her virtue further, Récamier's right hand is unfurled by her side as she slightly tilts her head as if she observes her viewer. Satish Padiyar considers the positioning of Récamier's hands as 'beautiful, but without any particular function'. ${ }^{41}$ I believe this to be a rather limited perspective on the expressivity of hands. Hands can convey a wealth of information; a painting of a woman holding an infant's hand, for example, points to a maternal bond. Here, Récamier's hands are not clenched or clasped, but rather, her palm is open and at rest, suggesting her ease at being observed. This presentation is at odds with the image of a woman who was said to dislike attention to a such point that she rarely appeared in public. Here, an open palm beckons the viewer forward, encouraging a closer look. Yet, Récamier ensures protection from malevolent thinkers and critics, such as those writing for the Gazette de Merveilleuses. Her white dress functions as an aesthetic pointer to her unblemished reputation; her unadorned neck and arms emphasise her contempt for worldly goods. The simplicity of Récamier's self-fashioning did not only seek to deflect accusations of vanity, but further co-opted the aesthetics of the Revolution. Her lack of diamonds or wigs reminds us of the wives of artists who famously donated jewels to the Republic during the Revolution, yet she wore an expensive Kashmir shawl. This paradox illustrated the duality of Récamier's character: seductive, alluring, and dazzling as she dances, but natural and simple in her look. Récamier's public image echoes revolutionary ideals of femininity - silent and classically dressed - but transforms them according to the values of a more permissive and politically open society. ${ }^{42}$

In further observation of Gérard's portrait of Récamier in her golden shawl, we are reminded of Darcy Grigsby's study on the trope of illicit sexuality in colonial representations of societies loosely defined as the 'Orient'. ${ }^{43}$ The latter term, it is important to note, is a generic term used 
in early modern European discourse to refer to societies in North Africa and the Middle East. ${ }^{44}$ Grigsby focused primarily on Mameluke soldiers, the military dynasty ruling Egypt, who Napoleon and his soldiers encountered in Cairo and Alexandria during their I 798 military campaign. Mamelukes, Grigsby argued, were often sexualised and depicted as emotional, passionate, and libidinous, in pointed contrast to the rational figure of the Frenchman. As Mamelukes were frequently eroticised, such discourse extended to their garments. Woodruf Smith points to foreign imports as serving as 'tokens of the excitement supposedly available in the lands they came from' and we may imagine a similar sentiment in the painting of Récamier. ${ }^{45} \mathrm{~A}$ Kashmir shawl is a sensual garment; the soft goat-hair fabric is warm and can be wrapped around the wearer's body like a blanket, suggesting the intimacy of a private space. A shawl from Kashmir adds a flair of excitement, rather than mimicking how and why the wrap was worn in its country of origin. Mameluke men used wraps of this kind as turbans and sashes, wrapping them around their heads and waists. The procurement of these objects belonged to a long-established network of trade routes within Asia, connecting Kashmir's initial site of production, the city of Leh in Ladakh, to far-reaching sites of consumption including China, Tibet, Iran, and Egypt. ${ }^{46}$ Napoleon and his officers, intrigued by the fine quality and vivid colours of Kashmir shawls, began sending them home as gifts. Following the campaign, demand for Kashmir remained high, and French consumers purchased shawls through the Russian fair at Nizhnii Novgorod, as well as through merchants in Istanbul and Moscow. ${ }^{47}$ Due to its steep price, the Kashmir shawls became the sartorial trademark of a small, rarefied social group.

In the pages of the Journal de Dames et de Modes, this luxury commodity contributed to a European perception of the Orient as flamboyant and adventurous. The same was thought to be true of the fashionable French wearers. Furthermore, Récamier's shawl dance was symbolic of France's global presence because it was a sartorial legacy of the Egyptian campaign. In this regard, she is representative of the French empire abroad, and by donning the shawl, she reminded her audience of this cultural domination. But at the same time, the shawl's qualities divulge a moment in which Récamier became the Other. This occurred within a social space - the salon - that she wholly commanded. As Lenormant observed, it was Récamier who decided when and whether to dance. When she danced, she shared 
the qualities of the shawl, and through her movement, she embodied the sensual accessory before her audience. Her performance created a social space which she controlled and moved within. In turn, the shawl encapsulated her vivacity and sensuality, narrating her control as she weaved its material through her fingers, and draped it along her shoulders to reveal or conceal skin as she wished. It must have been a bodily spectacle, producing a space for multiple admiring looks. It was a visual manifestation of her creativity that she shared with an elite audience. Not unlike an artist, Récamier created and performed a 'succession of harmonious attitudes' which were enhanced by the shawl as it clung to her body, exposing or hiding it, as she shifted from the docile to the erotic. ${ }^{48}$

In Sartorial Self, Claire E. Cage explored women's enthusiasm for neoclassical dress as part of their bid to resemble classical statues. We may apply a similar reasoning here: the shawl frames its wearer, enabling their transformation into a living work of art. Contrary to the cold, inanimate statue, however, Récamier's use of the garment emphasises both movement and her sensuality. Rather than highlighting the potential discomfort such a moment of sensual assertiveness may provoke, as Lajer-Burcharth did in her analysis of Chateaubriand, we may further interpret it as a moment in Récamier's creative agency, a performance piece in which she conveys her role as an arbiter of taste.

\section{Conspicuously hidden, silently expressive: an enduring paradox}

Women who care about, work on, and use their appearance are often dismissed as vain, a point of critique which still holds true for scholarship on Récamier today. Susanne Hillman recently equated the salonnière with the Directoire equivalent of today's 'empty celebrities': 'to a greater or lesser degree, virtually all contemporaries agreed that Juliette Récamier was famous because she was beautiful'. ${ }^{49} \mathrm{I}$ am not interested in Récamier's beauty or the role her physical appearance played in boosting her reputation. Rather, my focus is on an element Hillman overlooked: the complexity with which she navigated her fame to both dissuade detraction and maintain public interest. Récamier may have inspired many men to offer declarations of love, but she also rejected a number of social invitations, ensuring lengthy gaps between public appearances. In his memoirs, Matthieu Mole remarked that Récamier's 'rare, almost mysterious appearances at the theatre and in 
public places had given her [...] a celebrity that no other woman of her time possessed' ${ }^{50}$ As her dance reminds us, Récamier not only occupied the space of the salon that she independently controlled, but she also carefully managed the exposure of her body. Hillman's analysis of an engraving in which Récamier, dressed in her trademark white gown and Kashmir scarf, visited a group of Spanish prisoners in Lyon, illustrates Récamier's narrative of artifice, or as she argues, a publicity stunt which exuded both 'sanctity and charitable condescension towards the incarcerated men'. ${ }^{51}$ I would suggest that such public acts share something with Napoleon's staged acts of benevolence; in fact, Grigsby's compelling analysis of the Corsican in Egypt, as represented in Antoine-Jean Gros' Bonaparte Visiting the Plague Victims of Jaffa (I 804) is strikingly similar. ${ }^{52}$ Both are public acts, memorialised as an image to incite public admiration and flatter the bountiful nature of their main character. Yet for Hillman, Recamier's control over her public persona is simply seen as disingenuous.

Récamier's interest lay not in vocalising a particular political or ideological platform. She rarely articulated her own opinions on state affairs, and despite her intimate friendships with many literary figures, she never attempted to write or publish. Whilst this might suggest Récamier's timidity or intellectual vacuity, I suggest that Récamier understood the risks of over-exposure. Allowing herself to be seen and heard so infrequently increased, rather than diminished, the public's fascination with her. Simultaneously, it further re-affirmed the so-called passivity of her public role. For a woman seen so rarely in society was surely little threat to the public, that is the masculine realm of politics. In her own apolitical sphere, however, there was still a culture that is very much political: the threat Récamier's salon presented was social fluidity, an idea which unnerved Napoleon. Her extensive and far-reaching network of friends was described once again by Lenormant, who observed that Récamier 'embraced elements the most diverse and discordant in the newly formed society of Paris - the remnant of the old noblesse - combined with the new men who were indebted to talent and military glory'. ${ }^{53}$ She had a particular skill for uniting people, useful in a city shaped by political fracture. Récamier, Sainte-Beuve stated in his memoir, 'disarmed anger, softened asperities, smoothed over all the roughness, and inoculated everyone with indulgence' ${ }^{54}$ Of course, such fluidity was only available to the upper class. What was remarkable about Récamier was her 
ability to entertain and charm visitors across the French elite landscape. At her salon, the old aristocracy intermingled with the newly moneyed classes. Such inclusivity of both pre- and post-revolutionary wealth secured Récamier's influence and it was difficult to find any elite group that did not boast at least one admirer of hers. Describing her as 'ma chère Juliette', Napoleon's brother Lucien liked to sign off his letters to Récamier as Romeo, imagining himself as her ill-fated lover. ${ }^{55}$

For the most part, historians have concluded that Napoleon's dislike of Récamier came from her friendship with Madame de Staël, a staunch opponent and critic of Napoleon. However, we can point to at least one example of Napoleon's unique discomfort with Récamier and her salon. Upon being told that several of his ministers had attended Récamier's salon, the First Consul declared that anyone who further socialised at 7, Rue de Mont-Blanc would be considered 'a personal enemy'. ${ }^{56}$ Ultimately, what Récamier used to protect herself from public criticism threatened her unravelling: an apolitical salon culture emphasising harmony over division was all the more dangerous. Unlike de Staël, whose allies and friends fell neatly within the category of Napoleonic detractors, Récamier could not be so easily sequestered. Her influence was widespread, and this was seen as a threatening for the newly minted leader who sought to consolidate Parisian society under his exclusive influence.

In light of this, Récamier's silent benevolence - the vapidity described by Hillman and the object-like role suggested by Lajerth Burcharth - no longer seems convincing. The image of Récamier that emerges through my analysis is the image of a figure who wanted to be seen and heard, a woman who managed her public exposure with unusual, and at times paradoxical, strategies in order to sustain the interest of her contemporaries. Her actions made it possible for her legacy to defy easy assessment long after her death. We may leave Récamier with a final anecdote from Lenormant. Once widowed, Récamier gifted Gérard's portrait to Prince Augustus of Prussia, a longstanding admirer. Following his death in I842, the painting was returned to its original proprietor. Paying a visit shortly thereafter, Lenormant recalled a sixty-five-year-old Récamier clasping her daughter's hands, gesturing to the painting and declaring: 'This is what I was forty years ago' ${ }^{57}$ Perhaps it is the melee of fascination, intrigue, and mystery, so perfectly encapsulated by Gérard's portrait that ensured its enduring place in 
Récamier's heart. It is a visual testimony to the public persona she had so carefully crafted and honed, an enigmatic image which continues to generate discussion to this day.

\section{Acknowledgements}

I would like to thank my supervisors, Mechthild Fend and Jennifer Rushworth, for their thoughtful comments on this research. I would also like to express my gratitude to the internal and external reviewers for their guidance and insights in putting this article together.

\section{Notes}

I Laure Junot Abrantes, 'The Memoirs of the Duchess of Abrantes', in Atheneum, vol. 3 I (I832): 39I.

2 Henry Dwight Sedgwick, Madame Récamier: The Biography of a Flirt (Indianapolis: Bobbs-Merrill Company, I940), 37.

3 Theresa Dolan, 'Fringe Benefits: Manet's Olympia and Her Shawl', Art Bulletin 97, no. 3 (20 I 5): $42 \mathrm{I}$.

4 Susan Siegfried, 'Expression d'une subjectivité féminine dans les journaux pour femmes, I800-I 840', in Plumes et Pinceaux: Discours de femmes sur l'art en Europe (Dijon: Publications de l'Institut national d'histoire de l'art, 20 I2), I.

5 Amy Freund, Portraiture and Politics in Revolutionary France (University Park, PA: Penn State University Press, 20I4), 4.

6 Freund, Portraiture and Politics, 4.

7 Ewa Lajer-Burcharth, Necklines: The Art of Jacques-Louis David After the Terror (New Haven, CT and London: Yale University Press, I999), I 8.

8 Lajer-Burcharth, Necklines, 258.

9 Lajer-Burcharth, Necklines, 259.

Io Claire E. Cage, 'The Sartorial Self: Neoclassical Fashion and Gender Identity in France, I797-I804', in Eighteenth-Century Studies 42, no. 2 (Winter 2009): I94.

I I Cage, 'The Sartorial Self, 205.

I 2 Cage, 'The Sartorial Self, 205.

I 3 Cage, 'The Sartorial Self, 205.

I 4 'La voici: consultez les statuaires antiques, elles donnaient aux femmes la ceinture de Junon; celle de Diane était pour les vierges. Le premier est placé sous la poitrine; elle soutint la gorge. La seconde était sur les hanches: elle marquait la taille'. L'Arlequin, ou Tableau des modes et des goûts, Premier Trimestre (Paris: Alexandre de Ferrière, an VII I 798-99), 42 .

I5 Isaphene M. Luyster, Memoirs and Correspondence of Madame Récamier (London: British Library, I 867), 32.

I6 Ibid.

I7 Exposition Juliette Récamier, muse et mécène, exh. cat., Stéphane Paccoud (ed.) (Montreal: Encyclopaedia Universalis, 20 I6), 82.

I 8 Exposition Juliette Récamier, 58. 
I9 Lenormant, Memoirs, I3.

20 May Berry, Extracts from Journals and Correspondence of Miss Berry from 1783 to 1852, vol. II (London: Longmans, Green and Co, I865), I9I.

2 I Berry, Extracts, I9I.

22 Antoine Lilti, The World of Salons: Sociability and Worldliness in Eighteenth-century Paris (Oxford: Oxford University Press, 2015), 6.

23 Sarah Horowitz, Friendship and Politics in Post-Revolutionary France (University Park, PA: Penn State University Press, 2013), I39.

24 Cage, 'The Sartorial Self, 204.

25 Horowitz, Friendship and Politics, I39.

26 Benjamin Constant, 'Memoire de Juliette', in Principes de politique et autres écrits (juin 14juillet 1815) (Tubingen: Max Niemeyer Verlag, 200I), $33 \mathrm{I}$.

27 Translated excerpts from the memoirs of M. Ch. de Lomenie are included in Alys Hallard, Madame Récamier: From the French of Edouard Herriot (Portsmouth: W. Heinemann, I906), 383. The original documents have been lost.

28 Pierre-Simon Ballanche, Lettres de Ballanche à Madame Récamier: 1812-1845 (Paris: Honoré Champion, I996), I93.

29 Lenormant, Memoirs, I8.

30 Amelia Rauser, The Age of Undress: Art, Fashion and the Classical Ideal in the 1790s (New Haven, CT, and London: Yale University Press, 2020), Io.

3 I Adams, Venus of the Capital, I5.

32 Adams, Venus of the Capital, I6.

33 Lenormant, Memoirs, 376.

34 Lenormant, Memoirs, xii.

35 Lenormant, Memoirs, xii.

36 Sarah Davies Cordova, Paris Dances: Textual Choreographies in the Nineteenth-century French Novel (Brooklyn: International Scholars Publications, I999), I.

37 Pierre Larousse, Grand dictionnaire universel du XIXe siècle, T. Onzième (Paris: P. Larousse, I 866), 27I.

38 Journal de Dames et de Modes, I7 August I798, 2. Bibliothèque nationale de France. Original French: 'C'est eux que nous suivrons en lunettes, aux bals, en promenades, ce sont leurs vêtements que nous copierons [. . .]'. Translation by the author.

39 Michelle Perrot, The Bedroom: An Intimate Story (New Haven, CT, and London: Yale University Press, 2018), I26.

40 Dolan, 'Fringe Benefits', $42 \mathrm{I}$.

4I See Padiyar, Les Lettres, 20. 'In François Gérard's painting which bears the same title, a little later (I802-I805), both hands rest softly on the bed, beautiful but without particular function'.

42 Dominique Godineau, The Women of Paris and their French Revolution (Berkeley: University of California Press, I998), 29.

43 Darcy Grimaldo Grigsby, Extremities: Painting Empire in Post-Revolutionary France (New Haven, CT, and London: Yale University Press, 2002), 80.

44 Edward Said coined the term 'Orientalism' as part of a discursive field which shaped cultural conventions around Arabic populations in early modern European scholarship. Edward Said, Orientalism (New York: Pantheon Books, I978), 6. 


\section{OBJECT}

45 Woodruff D. Smith, Consumption and the Making of Respectability, 1600-1800 (London: Routledge, 2002), 76.

46 Michelle Maskiell, 'Consuming Kashmir: shawls and empires, I 500-2000', Journal of World History I3, no. I (Spring 2002): 30.

47 Maskiell, 'Consuming Kashmir', 39.

48 It should be noted that the original performer of the shawl dance was Emma Hamilton, whose 'Attitudes' performance was replicated in salons and drawing rooms throughout Europe. For recent scholarship on Hamilton, see Ersy Contogouris, Emma Hamilton and Late Eighteenth-Century European Art: Agency, Performance, and Representation (Abingdon: Taylor \& Francis, 20I 8).

49 Susanne Hillman, 'Empty-Handed Beauty: Juliette Récamier as pseudo-event', Celebrity Studies 7, no. 4 (20I6): 2 I 7.

50 Antoine Lilti, The Invention of Celebrity (Cambridge: Polity, 20 I7), 330.

5 I Hillman, 'Empty-Handed Beauty', 208.

52 Grigsby, Extremities, 65.

53 Lenormant, Memoirs, 376.

54 Steven Kale, French Salons (Baltimore: John Hopkins University Press, 2004), I09.

55 Napoleon Bonaparte, Bonaparte et ses mémoires, 1775-1840 d'après les papiers déposés aux archives étrangères et d'autres documents inédits (Paris: Charpentier, I 882), 276.

56 Juliette Récamier, Souvenirs et correspondance tirés des papiers de Mme Récamier (Paris: Bibliothèque nationale de France, I 860), 90.

57 Lenormant, Memoirs, 33. 